DOI: 10.17951/lrp.2018.37.2.75-89

\author{
IRYNA PALASEVYCH \\ Drohobych Ivan Franko State Pedagogical University \\ ORCID: https://orcid.org/0000-0003-0596-6835
}

\title{
AESTHETIC UPBRINGING OF SENIOR PRESCHOOLERS
}

\begin{abstract}
The essence of the aesthetic education of preschoolers, which involves the formation of the ability to perceive, feel, understand beauty in life and art; the desire to participate in the transformation of the surrounding world according to the laws of the beauty; the development of artistic-aesthetic competence (emotional-sensual, cognitive, practical, value-based, creative components) are discussed in this research. The content of aesthetic education of preschoolers, which means the formation of children's aesthetic attitude to reality and aesthetic activity, as well as mastering of the aesthetic culture fundamentals, the development of aesthetic perception, aesthetic senses, ideas and judgments, aesthetic taste and so forth are analysed.

Well-timed communication with works of various types of art, introduction of the child into the world of beauty and harmony is an important task of aesthetic education. Beauty is inseparable from kindness, it ennobles life, inspires to good deeds. An adult helps to find, feel and understand the beauty of poetry, music, and painting. Through art a child can understand more about everything in the surrounding world: nature, objects, work, spiritual heritage.

The level of artistic-aesthetic development of a senior preschooler is manifested in a sense of satisfaction from the process and the results of creative artistic-aesthetic activities. This development is established by the art's influence on the growth of the aesthetic culture level of the child's personality, level of aesthetic qualities and abilities, aesthetic experience and aesthetic attitude to the surrounding world, the process and the results of child's creativity.
\end{abstract}

Keywords: aesthetic education, the content of aesthetic education, the task of aesthetic education, means of aesthetic education, artistic-aesthetic competence, senior preschoolers

The ability to perceive and transform reality by the laws of beauty is a necessary element of spiritual wealth of an individual. Without aesthetic upbringing, formed aesthetic perception, tastes, artistic abilities it is impossible to imagine person's comprehensive harmonious development. Therefore, ever since a person begins to perceive the world, it is very important to teach a person to see, feel and understand beauty and all its manifestations. 
Senior preschool age is significant in this context, especially when the emotional-sensual sphere is being enriched, the aesthetic attitude towards life is being formed, and the perception and understanding of beauty in art, nature, and people's relationships is constantly developing. Forms of moral, aesthetic and cognitive perception (compassion, sensitivity, sense of duty, mutual help, experience of success-failure, curiosity, etc.) become more mature.

Aesthetic education acquires a special valuable meaning in the preschool educational institution's pedagogical process, and the task of educators is to use as much as possible means for the aesthetic development of preschoolers. Engaging kids into various activities helps their spiritual and aesthetic enrichment, improves the formation of the qualities required for further life. At the same time, the objective value of each of these types of activities is different but significant for the child.

Aesthetic education of the individual is the subject of scientific analysis of philosophers (T. Andrushchenko, M. Berdiaiev, Ie. Hromov, L. Levchuk, V. Movchan and others), who consider it as a means of involving children and youth in spiritual and culturological social values; of teachers (A. Zaporozhets, I. Ziaziun, O. Kyrychuk, B. Kobzar, O. Semashko, V. Sukhomlynskyi and others); and of psychologists (H. Ball, I. Bekh, T. Kyrylenko, V. Moskalets). L. Kondrashova, N. Myropolska, L. Khliebnikova, O. Sapozhnik, H. Sahach and others work on problems of aesthetic education's categorical notions. Their research is conceptual for pedagogical science and has become the basis for today's achievements in aesthetic education under conditions of national revival.

H. Bielienkaia, A. Bogush, A. Kononko, N. Lysenko, V. Marshytska, H. Tarasenko, L. Fesiukova and others devote their scientific research to the problems of improving the content of aesthetic education and searching for its new nontraditional forms, methods and techniques.

\section{ESSENCE AND CONTENT OF AESTHETIC EDUCATION OF PRESCHOOL-AGE CHILDREN}

In today's world, aesthetization deeply penetrates into human life; reality acquires features that were previously characteristic of art only. Modern aesthetic consciousness is being formed under the influence of aestheticization processes. That aesthetic consciousness is a spiritual foundation that provides harmonious unity and internal interrelation of various manifestations of a person's and society's spiritual life as a whole. Aesthetic consciousness is a coherent, emotionally colored reflection of natural and social reality in the unity of its essential definitions and sensual originality. Reflections of the surrounding world in the 
aesthetic consciousness are accompanied by the appearance of special complex experiences associated with the feelings of the sublime (majestic), beauty, tragedy, and comicality. The aesthetical feeling as an experience is not always based on intellectual knowledge. At the same time, both positive and negative aspects of the environment are evaluated and experienced equally (Hazniuk et al. 2011).

Aesthetic consciousness is a complex of feelings, conceptions, views, ideas; a special spiritual formation that characterizes the aesthetic attitude of a man towards reality. Interaction with the real world is perceived, evaluated and experienced individually on the basis of existing social ideals, tastes, and needs.

One way or another, modern man's formation of aesthetic consciousness and aesthetic attitude to reality must have a positive orientation. This means aesthetic mastery of the world, which includes and unites such processes as perception of the world, spiritual reworking and practical transformation. Actually, the development of person's aesthetic consciousness, his/her ability to be creative in various life activities characterizes the level of individual's aesthetic culture.

Aesthetic education should contribute to the emergence, consolidation and development of aesthetic values and motivations, and formation of the aesthetic culture.

Aesthetic education is a wonderful, powerful source of moral purity, spiritual wealth, and physical perfection. Being an organic component of the personality formation, aesthetic education provides the dialectical unity of the mental, moral, physical and social formation of man. Aesthetic education largely determines and enhances mental, emotional, spiritual activities; contributes to significant changes in beliefs, expands the experience, as well as the complex development of the individual. Scientists explain a significant role of aesthetic education in shaping the personality by the fact that it attracts man to the beautiful world, ennobles, helps to perceive better, to understand the beauty in the surrounding life, and appreciate the works of art.

Beauty is inextricably linked with the human soul, its work, behavior, language, appearance. The creative soul of mankind, including the Ukrainian nation, has created the true masterpieces of cultivating a sense of beauty: from the mother's lullaby to the complex kinds of art that man can master throughout life. Being aimed at the formation of a creative person capable of adequately perceiving the beauty and ugliness, endued with a sense of measure in the creation of artistic values, aesthetic education involves the development of a sensual sphere, which is closely linked with the moral world of man. Watching the beautiful, a person cannot remain indifferent, he/she is experiencing sympathy or hatred for the observed (Kostiuk 2011, p. 280). An attitude towards reality is formed with the enrichment of aesthetic feelings, quantitative changes in perception, complication 
of aesthetic needs, judgments, acquisition of emotionally-shaped skills of objects assessment, and the development of an ideal. Aesthetic development is carried out in such a way, which requires the presence of a specially organized pedagogical influence on the perception and consciousness of the individual.

According to the aesthetics dictionary, aesthetic education refers to a system of actions aimed at the developing and improving the ability of a person to perceive, correctly understand, appreciate, and to create beauty elevated in life and art (Petrushenko 2009, p. 64).

S. Honcharenko notes in the Ukrainian pedagogical dictionary that aesthetic education is an integral part of the educational process, which is directly aimed at the a) formation and cultivation of aesthetic perception, tastes, judgments, artistic abilities of the individual, b) development of person's ability to perceive and transform reality according to the laws of beauty in all spheres of human activities. Aesthetic education is also aimed at upbringing humanistic qualities, interests and love for life in its various manifestations (Honcharenko 1997, p. 119).

In the pedagogical dictionary by M. Yarmachenko, one can find somewhat generalized definition of the notion. Aesthetic education is defined as "the formation of person's aesthetic experience which is necessary for his/her self-affirmation" (Yarmachenko 2001, p. 175). And "aesthetic experience" means unity of views, ideals, perception, tastes, needs, etc.

O. Dubaseniuk interprets aesthetic education as "the pedagogical process of interaction between the teacher and pupils, aimed at forming aesthetic culture and developing the aesthetic attitude of an individual to life; gaining the ability for creative activities according to the laws of beauty" (Dubaseniuk 2004, p. 359). I. Ziaziun and H. Sahach treat aesthetic education as "the formation of person's aesthetic attitude to reality". This attitude creates personality's orientation in the world of aesthetic values, aesthetic tastes and ideals, and, at the same time, creates his/her ability for aesthetic perception and experience, ability to live according to the laws of beauty, to the creation of aesthetic values in art, work and life, actions and behavior (Ziaziun, Sahach 1997, pp. 32-33).

The Encyclopedia of Education does not define the aesthetic education, but its authors offer an interpretation of a somewhat broader, syncretic concept, namely aesthetic education: "the process of pedagogical interaction aimed at the formation of aesthetic knowledge, skills and experience of artistic-aesthetic activities; the development of person's aesthetic consciousness, emotional and valuable attitude to art, man and world" (Encyclopedia of Education, 2008, p. 264).

O. Sapozhnik considers aesthetic education as a complex philosophical and socio-pedagogical system, which forms the basis of general spiritual culture of a man. This is a "purposeful, organized and controlled pedagogical process of 
forming aesthetic consciousness of the individual, development of his/her emotional and perceptional sphere and artistic and creative activity" (Sapozhnik 2002, p. 24).

In the context of our research, the idea of I. Kharlamov that in aesthetics, beauty is connected with the artistic reflection of reality in the minds and feelings of a person, with his/her ability to understand beauty, to follow it in life and to create is worthy of attention. And the essence of aesthetic education means the organization of "a variety of artistic-aesthetic activities aimed at a) forming the abilities of a full-fledged perception and correct understanding of the beautiful in art and life; b) the development of aesthetic concepts, notions and tastes, as well as the development of creative abilities" (Kharlamov 2002, p. 435).

Aesthetic education harmonizes and develops all spiritual qualities of a person, which are necessary in different spheres of creative processes. Upbringing by beauty and through beauty not only creates the aesthetic-value orientation of the individual, but also develops creative abilities, the ability to create aesthetic values in the sphere of work, life, actions and behavior, and certainly in the arts. The development of essential qualities of an individual, which influences his/her formation, takes place simultaneously with the development of aesthetic abilities.

L. Kalinina sees the main task of aesthetic education in forming artisticaesthetic and creative abilities of a person (Kalinina 2006, p. 24). Aesthetic ability is defined as a set of individual psychological features, which give an opportunity to perform creative aesthetic activities: to aesthetically perceive and experience the phenomena of reality and art, to evaluate them by means of judgement, taste and comparison with the ideal, to create new aesthetic values (in work, behavior, science, technology, and art).

Artistic abilities are peculiar manifestation, specification and specialization of aesthetic abilities. Artistic abilities are not only the capacities of aesthetic perception, experience and evaluation of works of art, but also the abilities to create artistic values. Artistic-aesthetic abilities are manifested in the propensity, need, capacity, ability to perform artistic activity, and effortlessness of mastering creative skills (Oderiy, Rodzymakha 2010).

Well-timed communication with works of various types of art (musical, visual, literary, theatrical, architectural, decorative and so on) opens the world of existing beauty to a man. That communication shapes man's beliefs, influences his behavior, gives great opportunities for experiencing the beautiful and developing emotionally-aesthetic feelings.

According to A. Kuzminskyi and V. Omelianenko, the ultimate goal of aesthetic education is to form a person's readiness for aesthetic creative activities as an important component of aesthetic culture. There are various types of such activities: organization of aesthetic environment, where a person lives, works, studies, 
rests; specific creative activities in the sphere of art, literature, etc; propaganda of art, aesthetic ideals; aesthetic expressiveness in educational, industrial, domestic activities; identification of aesthetic culture in relations with people (Kuzminskyi, Omelianenko 2006, p. 190).

Thus, aesthetic education should contribute to the formation of person's approach to the world, which implies the need to improve the entire living environment. Aesthetic perception must be present in daily life, in relationships between people, attitude towards oneself, own actions, and native nature.

On the basis of the analysis of scientists' works, we can state that content of aesthetic education means the formation of aesthetic knowledge, skills, perception, interests, needs, assessments and tastes that are manifested in aesthetic activities; this is the formation of the aesthetic sphere of the individual.

The complexity of solving problems which deal with forming components of a preschooler's aesthetic education is determined with the age of a child. No feature can be completely formed during this period - they are at the stage of their initial formation. However, creating a foundation which will help to erect a "building" of the future aesthetically developed, creative personality is not only possible but also necessary, especially taking into account all the advantages that preschool age can create for a productive educational process.

The path of every child to the aesthetic world is complex, peculiar, and individual. This statement is fundamentally important. When working with the children's collective, the teacher should involve every kid into the creative process, in its richness and diversity.

The content of preschool children aesthetic education supposes the formation of their aesthetic attitude to reality and aesthetic activities, mastering the fundamentals of aesthetic culture, development of aesthetic perception, aesthetic judgments, aesthetic taste, etc. Aesthetic education begins in the early childhood with the development of aesthetic perception of reality (a specific activity which helps preschool children to develop the ability to perceive objects of the world from aesthetic point of view) and continues throughout their lives. From the psychological point of view, aesthetic perception nurtures observation, stimulates thinking, develops the ability to evaluate and express appropriate judgments. It contributes to the development of the emotional sphere, empathy, because every aesthetic phenomenon causes emotions of joy and passion. Intellectual and aesthetic development is intensified in the process of contemplating beauty (Palasevych 2012, p. 45).

S. Matvienko notes that in the preschool age, aesthetic perception has specific features due to age peculiarities, and it is distinguished by emotional immediacy, increased interest in the environment, vivid response when meeting a wonderful and outstanding thing, and attempting to provide an aesthetic characterization (Matvienko 2016, p. 72). 
Zh. Iuzvak claims that aesthetic perception consists of a) emotional (manifestations of joy, astonishment, admiration, which appear externally in facial expressions, movements, gestures, statements; the need for empathy of aesthetic emotions on the part of a significant person, manifested in the desire to draw his/her attention to the aesthetic object, mentioning it after a certain time) and b) cognitive components (aesthetic observation manifested in the ability to independently allocate an aesthetic object among others; the ability to express an aesthetic judgment about the object and its properties) (Iuzvak 2000, pp. 51-52).

In the process of perception and understanding of beauty, there appear aesthetic feelings, which are fixed in the aesthetic necessity and find their way out in various activities and the attitude of preschoolers to reality. The ability to respond emotionally to the phenomena of nature, the environment and evaluate them, is the basis for the formation of aesthetic tastes and ideals of children.

Aesthetic needs are an internal necessity to understand certain aesthetic values and the development of certain skills. Formation of aesthetic culture is an important component of the content of aesthetic education. I. Ziaziun, N. Myropolska, L. Khliebnikova consider this category as "the experience of the cult of light, which involves the obligatory sensory response of man to everything that takes place in the world that surrounds him/her" (Ziaziun, Myropolska, Khliebnikova 1998, p. 17). The word is a powerful factor in the formation of aesthetic culture. Aesthetic culture is a socially determined level of development of an individual's aesthetic principles, which provide him/her with readiness for activities in the field of art and aesthetics.

The experience of aesthetic activity is a component of aesthetic education. Aesthetic activity is aimed at: a) organizing the aesthetics of the environment, b) development of creative abilities of the individual in the field of music, fine arts, literature, theater studies, imagination, imaginative thinking, fantasy, c) propaganda of art, aesthetic ideals, d) self-education and self-upbringing for the purpose of spiritual and aesthetic enrichment of personality. Aesthetic activity is a continuous process of formation and realization of certain creative skills, abilities, harmonization of oneself and the world.

Taking this into consideration, aesthetic education can be regarded as a systemic activity aimed at developing the sensory sphere of the individual, his/her ability to perceive, to evaluate the phenomena of aesthetic reality by the laws of beauty; to enrich their inner world in the process of their perception; to create beauty in the natural and social environment; to multiply this beauty by the results of its own aesthetically significant activities.

All these qualities of an individual need to be developed beginning from the early childhood, focusing on certain directions, choosing the means, forms and 
methods taking into account the age peculiarities of children, especially peculiarities of their aesthetic perception.

\section{MEANS OF FORMATION OF SENIOR PRESCHOOLER'S ARTISTIC-AESTHETIC COMPETENCE}

Senior preschoolers have all the prerequisites for the formation of aesthetic culture elements. They have an understanding of diverse values, they are being introduced to various arts: fine arts, musical, theatrical, literary; they are able to respond emotionally to the manifestations of aesthetic in life and art, express their feelings in various artistic activities, they can evaluate their actions and deeds of others, they know rules and norms of behavior. Preschoolers are being taught foundations of aesthetic taste (sense of line, shape, color, rhythm, etc.).

A child possesses some features needed for the formation of aesthetic abilities: spontaneity, emotionality, expressiveness, openness to the world, playfulness. The direct manifestation of inner life is the completeness of aesthetic selfexpression. Aesthetic ability coexists with the aesthetic needs in childhood, and the special formation of aesthetic needs, the spiritual need for aesthetic experiences is inseparable from the formation of abilities to aesthetic activities. Such "aesthetic meeting" of the abilities with the needs creates the preconditions for the development of creativity and the formation of artistic-aesthetic taste of the child (Klokova 2011, p. 267).

A. Shevchuk also emphasizes that elements of child's personal aesthetic culture manifest themselves in aesthetic or artistic activities, which are aimed at the creative interaction with the environment and other people (Shevchuk 2012, p. 15). Therefore, nowadays much attention is paid to the aesthetic education of preschoolers, which is understood as the formation of children's aesthetic attitude to life, the development of perception and understanding of the beauty in art, artistic needs and the ability to create.

We can treat aesthetic development of preschoolers as the process of constant qualitative changes in relation to reality and art as the result of targeted pedagogical influences of the pre-school educational institutions, family and other social institutions, which is carried out through upbringing, education and self-education. Introduction of the child into the world of beauty and harmony is an important task of aesthetic education. Beauty is inseparable from kindness, it ennobles life, inspires man for good deeds. An adult helps to find, feel and understand the beauty of poetry, music, painting, and art, and to better understand everything that surrounds the child - nature, objects, work, spiritual heritage. 
The child must be taught that the world is filled not only with necessary, useful, but also with beautiful things. The educational effect means that the child should see, understand, feel, experience, and comprehend beauty. According to V. Sukhomlynskyi, beauty is a powerful means of raising the sensitivity of the soul, but without understanding and perception of beauty, without enthusiasm and inspiration, one will never see beauty in life, will not learn to fight evil. Beauty is a bright light that illuminates the world, corrects our spirit, our conscience, our feelings and beliefs. Truth and goodness reveal themselves through beauty (Sukhomlynskyi 1976, p. 410).

I. Kazmerchuk and M. Fedorova singled out the following tasks of aesthetic education of children in preschool educational institutions:

- to develop systematically the perception of beauty; develop child's aesthetic feelings and beliefs. All kinds of art, nature and life contribute to this, causing emotional feelings, joy, excitement, admiration;

- to involve children in the sphere of arts, raising their need and the habit of contributing elements of beauty to life, nature, and social relations;

- to form the basis of the aesthetic taste of children and the ability to independently evaluate works of art and phenomena of life;

- to develop artistic and creative abilities of children (Kazmerchuk, Fedorova 2012, pp. 109-110).

It should be noted that in the programs of development, education and upbringing of preschool children there is a separate section devoted to the artisticaesthetic and creative development from the early age. The artistic-aesthetic course is represented by the following types of work: reading and telling artistic works, staging and dramatization of fiction literature, music, visual activities. Realization of the tasks of the section "Creative Development" provides development of creative abilities of children, their imagination, independence in the embodiment of their plans, the search for ways to implement them. For this purpose, it is proposed to involve children in various types of work: staging, dramatizing the literary work with his/her creative rethinking, realizing a creative idea in the artistic activity, making products from a variety of materials, sketching, pantomime, research and exploration activities during the acquaintance of children with nature, etc. (Program of development of preschool child..., 2013).

Artistic-aesthetic development of children at different age stages has its own peculiarities, which determine the specifics of the organization of educational work in this direction. Peculiar to children of certain age category notions, skills (relative to various types of creative activity) are manifested in the formation of important components of artistic-aesthetic competence:

- emotional-sensory component (positive-emotional attitude to the surrounding world and works of art); 
- cognitive component (ideas about different types of art and their features and means of expressiveness);

- practical component (mastering the necessary artistic, creative skills, techniques of performing works);

- a value component (the presence of own aesthetic preferences, ratings and manifestation of artistic taste);

- creative component (manifestation of initiative, autonomy and creativity) (Program of artistic-aesthetic development..., 2013, p. 11).

Aesthetic upbringing of children takes place in various forms of artistic-aesthetic activity: in classes in fine arts and crafts, music, choreography, with acquaintance with works of fiction, visiting theater, museum, communicating with nature, etc. Senior preschooler is able to convey his/her attitude to various types of art; to name its main types (painting, graphic arts, sculpture, architecture, decorative-applied art); to tell one or two genres, for example, of fine arts (landscape, portrait) and names of subjects related to visual activities; to name some types of fine art (embroidery, carvings, easel, carpet weaving, etc.). Preschooler uses words to denote actions (to dwell, to color, to cut, to stick together, etc.); preschooler names color shades; takes on the role of "artist", "sculptor", "master", "designer", respectively, motivates the choice of activities and materials, conveys the characteristic features of objects (shape, proportion, color, texture, size) (Program of development of preschool child..., 2013).

The composition of child's drawings, applications, modeling, designing of objects and surrounding reality becomes more complicated, and the child actively and creatively expresses his/her emotional attitude to them, his/her work attracts by the sincerity of feelings and brightness of the colors. It becomes much more interesting for a child to work with peers, to determine the participation of everyone in the general composition, to create an artistic image, thereby drawing as a product of creative efforts becomes original and unique. The child reflects the characteristic features of the characters (kind, cheerful, evil) in the drawings, distinguishes real and fabulous, typical and special in design, modeling, and applications; notices deficiencies in own works, and child can aesthetically assess the end result of his/ her own artistic efforts.

Senior preschooler is enthusiastic and emotional while listening to music; defines the general character, the mood of a musical composition, associates a certain musical image with its own worldview. The desire to learn how to play musical instruments increases among the majority of children, as well as the ability to individually interpret, develop musical abilities. The child holistically characterizes a musical composition, distinguishes the properties of sound, individual means of expressiveness; differentiates various genres of musical art, combines it with dance moves, composes fairy tales, poems, short stories from heard melodies. 
Parents and educators should be careful about choosing musical works for listening. They have to offer child not only the light, rhythmic adult music, but also classical and children's. They help preschooler with determining the genre of a musical work, naming the playing instrument; and with guessing the pieces included in the musical quiz. It is wise to use music in audio and video recordings; to organize a run-through of children's content available for opera and ballet performances, visits to concerts, museums. It is important to teach a child to distinguish "music of nature" - singing birds, sounds of various insects, rustling leaves and waves of water, etc.; to compare natural music with created melodies, to find similarities and differences in them.

An adult exploits high-artistic music with vivid images, different moods, which can be used to recreate walking, running, jumping, moving hands in various ways. It is advisable to use musical-kinetic improvisation in stories to stimulate the individual creative manifestations of the child.

The senior preschooler has the following skills and competencies in the perception of theatrical art: he/she understands the content of the performance and theatrical image as a live acting with the use of speech, facial expressions, gestures, movements, music, dance, singing; preschooler empathizes the heroes of the plot, tells them how to behave in difficult situations; evaluates own actions and deeds of peers, comparing them with performances of characters of the show; imitates positive performances heroes; recognizes in silhouettes and shadows typical features of characters, appreciates the heroes (cunning, greedy, foolish, trusting); in gaming activities preschooler reflects the characteristic features of the image of theatrical characters. Also, the preschooler timely joins the group dramatization of fragments of the work; initiates the organization of "theatrical" games; takes active part in the preparation of dramatized games in stage activity; creatively transforms into characters, plays plots, expressively and playfully performs roles; brings creative pieces into the game by fairy tale; makes decorations, attributes, costumes; initiates the organization of "dramatizing games" and encourages peers to play the plots of literary works, fairy tales (Program of development of preschool child..., 2013, p. 228).

The child is familiar with the variability of the theaters (finger theater, table theater, toy theater, shadow theater, puppet theater, theater of pictures), understands the features and differences between them; he/she is familiar with theatrical terminology (three blocks: 1) actors - actor, cast, director, costume designer, makeup artist, spectator, success, applause, 2) performance - plot, script, premiere, part, intermission, final, 3) theater - poster, ticket, hall, wings, bell, curtain, balcony, scenery). The child consciously relates to the acquisition of knowledge about the theater as an expression of life situations in the acting game; has an idea about different types of theater, their features, purpose. 
Aesthetic environmental factors have a significant influence on the formation and development of creative impulse: the design of a kindergarten building, a site with its equipment and green plantations, object environment (design of the room): furniture, toys. Aesthetic environmental factors and their appearance, harmony of lines and shapes, color, variety of content, contribute to the formation of aesthetic perception, aesthetic feelings, assessments, foundations of aesthetic taste. Beautiful colorful interior decoration, furniture for children and adults, textile décor, the provision of children's activities by modern means, manuals, materials - all this will have a positive impact on the aesthetic education of children.

Matvienko substantiates the importance of combining artistic work and design as an important means of artistic-aesthetic education, and recommends the use of the following types of design: design for children (creation of an adult for a child of a comfortable material environment) and children's design (artistic work) (Matvienko 2016).

Children's design is a kind of artistic and constructive activity of preschool children, focused on the development of their aesthetic abilities and practical skills of artistic design. Here we talk about classes in artistic work and design that develop intelligence, the culture of speech and communication, the ability to analyze and generalize. Also, these classes develop creative abilities - spatial imagination, design-imaginative thinking in older preschoolers. Children, when participating in the creation of beauty objects, begin to realize their co-authorship, author's competence, they learn to organize their everyday life, using the experience gained in designing the space of a preschool institution.

Children play "dress your doll", "daughter-mother", arrange game-rooms and houses, build "fortresses" and "castles". They craft jewelry and souvenirs, make clothes for dolls, costumes and decorations for their performances and children's holidays. All this requires hand-work and children are involved in this activity with curiosity, wanting to do everything beautifully, with taste, neatness and diligence. Children's design creations can be used by themselves immediately after work, as well as in games and at home. In this case, a child feels like a creator, learns his personality, level of skills, while comparing his creations with the work of peers (style, creative manner).

Nature is an important factor when it comes to aesthetic upbringing of preschool children. Growing up in nature, the child learns to see the harmony, beauty, the richness of the colors of each season, to reproduce own impressions in oral narratives, drawings.

Communicating with nature brings the opportunity for children not only to feel its beauty, but also to develop and enrich their speech, because outdoor classes ensure moments when the teacher touches the children's hearts with the 
beauty of native land, the native word. Such classes teach children to see, perceive and experience the beauty of language and nature in a combination of colors and sounds, the desire to express their thoughts and impressions in "colors".

Evaluative and creative tasks will stimulate awakening of children's imaginative thinking and guarantee high intensity of the experiencing the beauty of the environment. These tasks could be a) verbal - choosing the comparisons ("What is November like?", "What is similar to dandelion?"); versification according to the proposed rhymes; creating monologues of nature objects ("I am the fastest stream of spring"; "Do not trample me, soft snowflake"); constructing dialogues with objects and phenomena of nature ("My conversation with a flower"; "Good day, spring" and so on); b) musical-plastic - to compose a song of spring rain; to dance the "dance of November"; to show the birth of February fair-maid with movements, etc.

Thus, the artistic-aesthetic development of a preschool child is facilitated by the support of an adult who wants to listen, respond, immit, repeat, examine, inspect and emotionally value the perception of the environment.

Observing and admiring the works of art, the child is able not only to see their characteristic features, but also to "plunge" into them, to hear the rustle of leaves, to feel the warm breeze on the cheeks, to enjoy plashes of sunlight on the palm, to inhale the aroma of autumn wood, sea breeze or apple-tree in bloom.

The kid strives to convey his/her feelings in words, intonation of the voice, and the desire to reproduce them in visible images prompts the kid to embark on drawing or making music.

After analyzing the views of scientists on that matter, we come to the conclusion that the aesthetic education of preschoolers is a) the development of their abilities to perceive, feel, understand beauty in life and art; b) the upbringing of children's desire to participate in transformation of the environment accordingly with the laws of beauty; c) the involvement of children into artistic-aesthetic activities according to their inclinations and interests, which contributes to the integral formation of aesthetic feelings, judgments, tastes and ideals, development of creative abilities. This phenomenon is a system, and its initial stage means formation of all components of aesthetic consciousness, and the final result is the development of a creative personality, which has a high level of aesthetic culture and feels socially valuable and self-significant. Achieving the goal of aesthetic education - the harmonious development of child's personality - is possible only through the complex solution of all its content and tasks. 


\section{REFERENCES}

Газнюк, Л.М., Могильова, С.В., М’яснікова, Н.О., Салтан, Н.М., 2011, Естетика. Київ: Конкорд.

Гончаренко, С.У., 1997, Український педагогічний словник. Київ: Либідь. Дубасенюк, О.А., 2004, Практикум з педагогіки. Київ: Центр навчальної літератури. Енииклопедія освіти, 2008, Київ: Юрінком-Інтер.

Зязюн, І.А., Миропольська, Н.Є., Хлєбнікова, Л.О., 1998, Виховання естетичної культури школярів. Київ: Ізмін.

Зязюн, І., Сагач, Г., 1997, Краса педагогічної діі. Київ: Українсько-фінський інститут менеджменту і бізнесу.

Казмерчук, І., Федорова, М., 2012, Естетичне виховання дошкільників засобами природи. Інноваційний досвід педагогів дошкільної та початкової освіти Житомирщини.

Калініна, Л., 2006, Естетичне виховання молодиих школярів як соціально-педагогічна проблема. «Рідна школа», № 3.

Клокова, Ю., 2011, Формування художньо-естетичного смаку в дошкільників. Вісник Інституту розвитку дитини (додаток): методичні та практичні матеріали. Вип. 2, Київ.

Костюк, С., Естетичне виховання дошкільника - складова гармонійного розвитку дитини. Вісник Інституту розвитку дитини (додаток): методичні та практичні матеріали. Вип. 2, Київ.

Кузьмінський, А.І., Омеляненко, В.Л., 2006, Педагогіка у запитаннях і відповідях. Київ: Знання.

Матвієнко, C.I., 2016, Художня праия та основи дизайну. Ніжин: Ніжинський державний університет імені Миколи Гоголя.

Одерій, Л., Роздимаха, А., 2010, Розвиток художніх та естетичних здібностей дітей старшого дошкільного віку. Актуальні пролеми психолого-педагогічного та соціального супроводу дитини на ранніх етапах соціалізації. Гуманізація навчально-виховного процесу, Спецвипуск 4, Ч. 1, Слов’янськ.

Паласевич, I., 2012, Зміст естетичного виховання дітей старшого дошкільного віку. Дрогобич, Актуальні проблеми дошкілля.

Петрушенко, О.П., 2009, Словник з естетики. Львів: Магнолія.

Програма розвитку дитини дошкільного віку «Украӥнське дошкілля», 2013, Тернопіль: Мандрівець.

Програма художньо-естетичного розвитку дітей раннього та доикільного віку «Радість творчості», 2013, Тернопіль: Мандрівець.

Сапожнік, О., 2002, Феномен естетичного виховання у вітчизняній науковій літературі. «Рідна школа», № 8-9. 
Сухомлинський, В.О., 1976, Вибрані твори. В 5-ти т., Т. 2. Київ: Радянська школа. Харламов, И.Ф., 2002, Педагогика. Минск: Университетское.

Шевчук, А., 2012, Дитина у світі культури: орієнтири до освітньої лінії. «Дошкільне виховання», № 9.

Юзвак, Ж., 2000, Естетичне сприймання: психологічний аспект. «Початкова школа», № 12.

Ярмаченко, М.Д., 2001, Педагогічний словник. Київ: Педагогічна думка.

\section{WYCHOWANIE ESTETYCZNE DZIECI W STARSZYM WIEKU PRZEDSZKOLNYM}

Abstrakt: W badaniu została przedstawiona istota wychowania estetycznego dzieci w starszym wieku przedszkolnym, co przewiduje kształtowanie zdolności dostrzegania, odczuwania oraz zrozumienia piękna w życiu i sztuce, chęci brania udziału w przetwarzaniu otaczającego świata według zasad piękna, rozwoju kompetencji artystycznej i estetycznej (komponent: emocjonalnie-zmysłowy, poznawczy, praktyczny, wartościowy, twórczy). Dokonano analizy treści wychowania estetycznego przedszkolaków, rozumiejąc je jako: kształtowanie u dzieci estetycznego stosunku do rzeczywistości i estetycznej działalności, opanowanie podstaw kultury estetycznej, rozwój estetycznego dostrzegania świata, estetycznych uczuć, pomysłów i opinii, estetycznego gustu itp.

Stosowny czas początku komunikowania się z dziełami sztuki, wprowadzenie dziecka do świata piękna i harmonii to ważne zadania wychowania estetycznego. Piękno jest nierozerwalnie połączone $\mathrm{z}$ dobrocią, to ono uszlachetnia życie, inspiruje do dobrego postępowania. Dorosły pomaga odnaleźć, odczuć oraz zrozumieć piękno poezji, muzyki, plastyki, a poprzez sztukę pozwala głębiej uświadomić sobie wszystko, co otacza dziecko: przyrodę, przedmioty, pracę, dziedzictwo duchowe.

Poziom artystycznie-estetycznego rozwoju starszego przedszkolaka ujawnia się w odczuciu zadowolenia z procesu oraz wyników twórczej działalności artstyczno-estetycznej. Rozwój ten jest spowodowany wpływem sztuki na: podwyższenie poziomu podstaw kultury estetycznej osobowości dziecka, ukształtowanie estetycznych cech i zdolności, estetycznego doświadczenia oraz estetycznego traktowania otaczającego świata, procesu i wyników własnej twórczości.

Słowa kluczowe: wychowanie estetyczne, treść wychowania estetycznego, zadania wychowania estetycznego, środki wychowania estetycznego, kompetencja artystyczno-estetyczna, dzieci w starszym wieku przedszkolnym 